\title{
Gaps in the Accounting of Stakeholder Integrations in HydroGIS Tools to Face the Challenge of Sustainable Urban Flood Management
}

\section{R.M.M. Pradeep and N.T.S. Wijesekera}

\begin{abstract}
The maturity of science had resulted in sophisticated urban flood management hydroGIS tools. However, persistent and increasing floods show that, thus far, no sustainable solution has been identified. A closer look reveals a shortfall in incorporating stakeholder requirements into these tools and how this should be done.
\end{abstract}

The objective of the present work is to evaluate the gaps in the integration of stakeholder requirements in HydroGIS tools for urban flood management and make necessary recommendations.

Expert discussion and systematic literature surveys were performed to capture the components and integration of activities in the ongoing decision-making systems using HydroGIS tools. A literature weighting scheme was developed to quantitatively assess the current level of stakeholder involvement and the associated gaps which demand urgent attention.

Development of the associated system revealed the main system components that need consideration as decision-makers, recipients, hydro, GIS, and HydroGIS models. The weights obtained indicated that the integration of hydro and GIS with the HydroGIS model deserve top priority.

The concerns of the HydroGIS model component are, therefore, vital for sustainable urban flood management as the component focally facilitates the optimisation of scientific and management concerns in decision making.

Keywords: HydroGIS tools, Sustainable Urban Flood Management, Recipients, Stakeholders

\section{Introduction}

\subsection{Background}

Due to the devastating repercussions, urban flood management has received decision-maker attention [1]-[3]. Flood management is commonly done by using hydrological models, and they manipulate the spatial data by combining Geographic Information Systems (GIS) [4], [5]. HydroGIS refers to a combination of hydrology and GIS components, while HydroGIS modelling tools are designed to perform hydrologic process computations using spatial information management capacity of GIS [6], [7]. Today, HydroGIS has become a popular tool for flood management, especially in urban areas. Hydrology has been practised over a long time, and continuous research has now reached maturity [8]. GIS came into play over fifty years ago. With the boost of technological advances, GIS is now used to improve hydrological data management with better efficiency, accuracy, and userfriendliness. Therefore, combined HydroGIS models are becoming popular tools [9]-[21].

Most environmental management decisions are influenced by dynamic stakeholders, rigid scientific assessments, and sensitive economic impacts [22]. Incorporation of stakeholders in decision making has been discussed since the 1960s [23], and by the $21^{\text {st }}$ Century, water professionals understood the importance of incorporating the general public, who was a missing component in water decision making [24]-[26]. The flood management decisions should be carefully incorporated with the stakeholder concerns to reach a practical and sustainable solution. Therefore, HydroGIS tool must be constructed to facilitate stakeholder needs to make and carry out sustainable flood management decisions [27].

Maj. R.M.M. Pradeep, B.Sc. (Hons) in MIS [NU1],

MSc(Civil) in UoM, Senior Lecturer (G II), Faculty of Computing, Kotelawala Defence University, Kandawala

Road, Rathmalana, Sri Lanka.

Email:pradeep@kdu.ac.lk

ORCID ID: https://orcid.org/0000-0001-8934-7534

Eng. (Snr. Prof.) N.T.S. Wijesekera, FIE(SL), B.Sc. Eng. Hons. (Sri Lanka), PG.Dip (Moratuwa),

M.Eng.(Tokyo),D.Eng. (Tokyo), MICE(UK), Chartered Civil Engineer, Chairman of the Board of Directors at Construction Industry Development Authority, Ministry of Urban

Development, Water Supply and Housing Facilities,

"Savsiripaya", 123, Wijerama Mawatha, Colombo 07, Sri

Lanka.Email:sohanw2@gmail.com

ORCID ID: https://orcid.org/0000-0003-0964-4331 
Nevertheless, HydroGIS's prime task is to perform accurate hydrological and GIS calculations, which require considerable processing time and effort. Then those stakeholder requirements place additional pressure on the resource requirement. As a result, HydroGIS tools face a challenge because of the need for efficient and effective tools [28].

Literature has several models and frameworks, such as Bhatt et al. [29] and Alcaraz et al. [13], that have attempted to develop suitable HydroGIS tools. However, the lack of examples and documentation makes it difficult to ensure whether the stakeholder requirements have been satisfactorily met. Literature also shows that, when tools are developed, the attention is either on hydrology, GIS, or stakeholders, but not all components in a holistic manner. It is also noted that many had identified different stakeholders, their roles, and a multitude of concerns [30]-[34].

Therefore, it is necessary to understand stakeholder concerns and integrate them into HydroGIS tools to develop a practically successful HydroGIS tool.

\subsection{Objective}

The objective of the present work is to find the status of stakeholder integration in HydroGIS models and recommend options for the systematic development of urban flood management tools.

\section{Method and Materials}

\subsection{Identification of Components of HydroGIS Tool Framework}

Four (04) approaches can be observed when integrating hydrological models and GIS models. This integration refers to the execution of process steps and data exchange between the hydrology model and the GIS model [31], [35], [36]. Reviewing those integrations could have conceptualised and identified associated specific stakeholder groups with their possible roles, as shown in Table 1.

The importance of public participation in water decisions has been discussed since the 1960s, and has become a world accepted practice by 2000 [23]-[26]; yet, the general public (recipients) is missing in the possible stakeholders (Table 1).

Therefore, 11 selected guidelines and HydroGIS tools ([4], [16], [44], [25], [37]-[43]) were evaluated to capture all possible stakeholder involvements, as shown in Table 2. It presents the extracted information corresponding to the role of GIS, hydrology, recipient stakeholders (users/public), and the decision-makers concerning either a tool or guideline. Table 2 provides a picture of the Integrations and their frequency of occurrence while providing a guideline to identify components in a HydroGIS model development framework for urban flood management. Accordingly, there are five main components: (1) HydroGIS Model, which carries out the integrated activities to develop flood management model. The

Table 1 - Review for Identifying HydroGIS Tools Users

\begin{tabular}{|c|c|c|c|c|c|}
\hline \multirow{2}{*}{$\begin{array}{l}\text { Hydro GIS } \\
\text { Integration } \\
\text { Approach }\end{array}$} & \multicolumn{2}{|c|}{ Execution of } & \multicolumn{3}{|c|}{ Author's Review } \\
\hline & Process steps & Data exchange & $\begin{array}{c}\text { Knowledge } \\
\text { required }\end{array}$ & $\begin{array}{c}\text { Possible } \\
\text { stakeholders }\end{array}$ & $\begin{array}{c}\text { Roles of } \\
\text { stakeholders }\end{array}$ \\
\hline $\begin{array}{l}\text { Loose } \\
\text { coupling }\end{array}$ & $\begin{array}{l}\text { Stakeholders } \\
\text { carry out the } \\
\text { process using } \\
\text { different } \\
\text { software }\end{array}$ & $\begin{array}{l}\text { Stakeholders } \\
\text { share the data } \\
\text { files among } \\
\text { different } \\
\text { software }\end{array}$ & $\begin{array}{l}\text { Spatial Data } \\
\text { formats, input } \\
\text { preparation, and } \\
\text { output } \\
\text { interpretation }\end{array}$ & $\begin{array}{l}\text { Modeller/ } \\
\text { Hydrology } \\
\text { Decision- } \\
\text { makers }\end{array}$ & $\begin{array}{l}\text { Modeller models } \\
\text { process steps and } \\
\text { data (metadata). } \\
\text { Decision-maker } \\
\text { flow the process by } \\
\text { manipulating the } \\
\text { data (actual data) }\end{array}$ \\
\hline $\begin{array}{l}\text { Tight } \\
\text { coupling }\end{array}$ & $\begin{array}{l}\text { Customised } \\
\text { software codes } \\
\text { carry out the } \\
\text { process } \\
\text { sequence }\end{array}$ & $\begin{array}{l}\text { Software codes } \\
\text { pass the data in } \\
\text { between } \\
\text { software }\end{array}$ & $\begin{array}{l}\text { Software coding } \\
\text { knowledge, and } \\
\text { understand the } \\
\text { architecture of both } \\
\text { software }\end{array}$ & \multirow{3}{*}{$\begin{array}{l}\text { Mainly } \\
\text { Software } \\
\text { developer. } \\
\text { Others are } \\
\text { Modeller and } \\
\text { Decision- } \\
\text { makers }\end{array}$} & \multirow{3}{*}{$\begin{array}{l}\text { Modeller models } \\
\text { process steps and } \\
\text { data (metadata) to } \\
\text { the software } \\
\text { developer. } \\
\text { Software } \\
\text { Developers } \\
\text { automate the } \\
\text { process. Decision- } \\
\text { makers use the } \\
\text { automated tool. }\end{array}$} \\
\hline $\begin{array}{l}\text { Embedding } \\
\text { GIS in hydro } \\
\text { model }\end{array}$ & $\begin{array}{l}\text { Hydrological } \\
\text { software carry } \\
\text { out all the } \\
\text { processes }\end{array}$ & \multirow{2}{*}{$\begin{array}{l}\text { Data passed as } \\
\text { Parameters } \\
\text { within the } \\
\text { modules in the } \\
\text { software }\end{array}$} & $\begin{array}{l}\text { In-depth knowledge } \\
\text { in GIS function } \\
\text { automation }\end{array}$ & & \\
\hline $\begin{array}{l}\text { Embedding } \\
\text { hydro model } \\
\text { in GIS }\end{array}$ & $\begin{array}{l}\text { GIS Software } \\
\text { carry out all } \\
\text { the process }\end{array}$ & & $\begin{array}{l}\text { In-depth knowledge } \\
\text { in Hydrology model } \\
\text { automation }\end{array}$ & & \\
\hline
\end{tabular}


HydroGIS modellers encapsulate the hydro and GIS models to perform the particular task; (2) Hydro Model which is created or selected to the specific situation. The Hydrology modellers perform the activity; (3) GIS model which is created by GIS modellers to provide required inputs and display outputs of the hydro model; (4) The decision-makers who make the flood management decisions finally; and (5) The recipient stakeholders who are the prime target of flood management service delivery.

When considering the frequencies of components' appearance in the 11 works of literature, nine had considered decision-makers while eight considered GIS modellers. As well, seven had considered hydrology modeller when six had considered HydroGIS modeller. The lowest consideration is to pay recipients, which is 5 out of 11 .

\subsection{Confirmation of Components}

An online expert review was conducted with local and international professionals to confirm the identified components [45]. The experts with substantial experience were selected from hydrology, GIS, water management, and public administration areas. They were invited to comment on the sufficiency of the components to the proposed model using a five-point Likert scale (5-Strongly agree to 1-Strongly disagree) and express the elaborations to be highlighted. Various studies have suggested utilising 5 to 20 varied numbers of experts for successful evaluation [46], [47]. Nevertheless, the present work considered nine experts are sufficient since a substantial accuracy can be achieved with nine samples in HydroGIS research [48]. All experts agreed with the findings but elaborated on whom to be included in each component. Table 3 shows the summary result of the expert discussion.

\subsection{Assessment of Integrations}

During HydroGIS tool development, the key is to find integration between each stakeholder group responsible for each component's activities. Evaluation of the integration between components would enable the assessment of current guidelines available for satisfactory HydroGIS tool development. A critical review of the existing literature was performed for this evaluation. Various types of scientific documents on HydroGIS systems were assessed by considering (1) the scientific value of the publication; (2) the depth of scientific investigation corresponding to each integration; and (3) the description of the influence of integration in publication.

Table 3 - Summary of Online Discussion

\begin{tabular}{|r|c|c|}
\hline Expert \# & $\begin{array}{c}\text { Experience } \\
\text { (Years) }\end{array}$ & $\begin{array}{c}\text { Acceptance } \\
\text { (5-Strongly agree to } \\
\text { 1-Strongly disagree) }\end{array}$ \\
\hline \multicolumn{3}{|c|}{ Elaborated on } \\
\hline 1 & 15 & Agreed (4)
\end{tabular}

Considered the recipients as vital in flood management and suggested three components: (1) a Social Science method to handle stakeholders; (2) Web-based tools for collaborating and educating the stakeholders; and (3) Hydrology model
2
12
Highly Agreed (5)

Considered that hydrology and GIS are the essential components in flood risk management.

\begin{tabular}{l|l|l}
3 & 45 & Agreed (4)
\end{tabular}

Commented that it is difficult to state what to include in the model; yet, it is necessary to consider the stakeholders and elements in the Flood managements phases, such as (1) Planning and forecasting, (2) Early warning and (3) Rescue. Highlighted the attention to additional stakeholders such as decision-implementors (Drainage constructors to drainage cleaners). 15 Highly Agreed (5)

Shared local experience highlights 14 different stakeholders and their role.

\begin{tabular}{l|l|l}
5 & 35 & Agreed (4)
\end{tabular}

Highlighted the trans-boundary decision-makers such as countries and flood management agencies.

$$
\begin{array}{l|l|l}
6 & 10 & \text { Agreed (4) }
\end{array}
$$

Suggested to consider three main models, i.e., (1)prediction model, (2)protection model, and (3) damage assessment model.

$$
\begin{array}{l|l|l}
7 & 30 & \text { Agreed (4) }
\end{array}
$$

Pursued on individual stakeholders such as Water Resources Department of the State, Ministry of Water Resources, prominent academic institutions of the locality, disaster management cell, local administration, active NGOs working in the related field and renowned hydrologists.

$$
\begin{array}{l|l|l}
8 & 42 & \text { Agreed (4) }
\end{array}
$$

Stated that the Government and the people in upstream and downstream are a specific component.

\begin{tabular}{l|l|l}
9 & 10 & Agreed (4)
\end{tabular}

Suggested to incorporate the following to the components: (1) Residents in flood-prone areas; (2) Government; (3) Commercial building owners in flood-prone areas; (4) Insurance providers; and (5) Researchers.

\begin{tabular}{|l|l|l|}
\hline Average & 23.8 & Above Average (4.2) \\
\hline
\end{tabular}


In the absence of a clear methodology to evaluate each of the above, the present work incorporated qualitative, judgmental specific Likert-scale based conceptualisation.

\subsubsection{Scientific Value of Publication}

The scientific value was assessed by considering the degree of review of contents in each publication. Assigned weight for each type was rationalised by using a small group discussion and a questionnaire survey. Thirtyfour university academics participated in the survey, and Table 4 describes the types and weights found in the study.

Table 4 - Literature Weights according to the Type

\begin{tabular}{|l|l|l|}
\hline $\begin{array}{l}\text { Literature } \\
\text { Type }\end{array}$ & W.* & Rational \\
\hline $\begin{array}{l}\text { Specific } \\
\text { Guideline/ } \\
\text { Standards }\end{array}$ & 3.13 & $\begin{array}{l}\text { Established reviewed } \\
\text { documents for new } \\
\text { technology considered } \\
\text { as appropriate for } \\
\text { practice }\end{array}$ \\
\hline $\begin{array}{l}\text { Book/ } \\
\text { Chapter }\end{array}$ & 4.56 & $\begin{array}{l}\text { Established reviewed } \\
\text { knowledge of seasoned } \\
\text { knowledge and practice }\end{array}$ \\
\hline $\begin{array}{l}\text { Indexed } \\
\text { Journal }\end{array}$ & 4.68 & $\begin{array}{l}\text { A thoroughly reviewed } \\
\text { knowledge }\end{array}$ \\
\hline $\begin{array}{l}\text { Peer- } \\
\text { Reviewed } \\
\text { Journal }\end{array}$ & 3.71 & $\begin{array}{l}\text { A well-reviewed } \\
\text { knowledge }\end{array}$ \\
\hline $\begin{array}{l}\text { Conference } \\
\text { Proceedings }\end{array}$ & 2.49 & $\begin{array}{l}\text { Ideas for discussion in } \\
\text { scientific forums which } \\
\text { require critical review }\end{array}$ \\
\hline $\begin{array}{l}\text { Web } \\
\text { Document }\end{array}$ & 1.65 & $\begin{array}{l}\text { Similar work evaluated } \\
\text { at an institutional level } \\
\text { and requiring further } \\
\text { review }\end{array}$ \\
\hline that may have value \\
\hline Monograph
\end{tabular}

\subsubsection{Depth of Scientific Investigation}

The depth of scientific investigation (conclusiveness) is the detail to which research has analysed and concluded a particular Integration. A 5-point Likert-scale was developed, the same as the previous (Table 5).

\subsubsection{Influence of Integration in Publication}

The third and critical influence identification criteria were assessed by the explicitness of the results point given in each document (influence). Again, a 5-class Likert-scale was used for this assessment (Table 6).

Table 5 - Classification of the Conclusiveness of an Integration

\begin{tabular}{|l|c|l|}
\hline Class & C. $^{*}$ & Description \\
\hline $\begin{array}{l}\text { VH) High** } \\
\text { High (H) }\end{array}$ & 5 & $\begin{array}{l}\text { Publication } \\
\text { comprehensively } \\
\text { analyses the integrations } \\
\text { in an identified system. }\end{array}$ \\
\hline Medium (M) & 3 & $\begin{array}{l}\text { A clear and specific } \\
\text { conclusion of integration } \\
\text { is presented. }\end{array}$ \\
\hline Low (L) & 2 & $\begin{array}{l}\text { An implicit result of } \\
\text { integration is presented } \\
\text { with analysis and } \\
\text { conclusion. }\end{array}$ \\
\hline $\begin{array}{l}\text { Indicates a relevant } \\
\text { result within the result } \\
\text { section or in discussion } \\
\text { but not conclude. }\end{array}$ \\
\hline $\begin{array}{l}\text { Very Low } \\
\text { (VL) }\end{array}$ & 1 & $\begin{array}{l}\text { Only an indication } \\
\text { reflects the value of } \\
\text { integration either in the } \\
\text { introduction or in the } \\
\text { literature review. }\end{array}$ \\
\hline * Conclusiveness &
\end{tabular}

Table 6 - Classification of the Description of the Influence of Integration

\begin{tabular}{|l|c|l|}
\hline Class & I. $^{*}$ & Description \\
\hline $\begin{array}{l}\text { Very High** } \\
\text { VH) }\end{array}$ & 5 & $\begin{array}{l}\text { Use of explicit terminology } \\
\text { such as "Very much, much, } \\
\text { highly, must-have, } \\
\text { important, sine-quo-none" } \\
\text { to describe the integration. }\end{array}$ \\
\hline High (H) & 4 & $\begin{array}{l}\text { Qualitative descriptions in } \\
\text { between moderate and } \\
\text { extremely high groups. }\end{array}$ \\
\hline Medium (M) & 3 & $\begin{array}{l}\text { Use of explicit terminology } \\
\text { such as "Moderate, also } \\
\text { important." }\end{array}$ \\
\hline Low (L) & 2 & $\begin{array}{l}\text { Qualitative description in } \\
\text { between moderate and } \\
\text { very low groups. }\end{array}$ \\
\hline $\begin{array}{l}\text { Very } \\
\text { (VL) }\end{array}$ & 1 & $\begin{array}{l}\text { Use of terminology such as } \\
\text { "Interesting, should } \\
\text { consider, supportive factor, } \\
\text { at least consider." }\end{array}$ \\
\hline
\end{tabular}

* Influence

\subsection{Evaluation of Literature}

Five possible integrations were discovered among the five main components identified earlier. Next, 32 works of literature were evaluated to find the values for conclusiveness (Table 5) and influence (Table 6) of each integration. With the use of publications' Article weight (Table 4), conclusiveness and 
influence values, a Reclassification Matrix (Table 7) was developed using the equal weight method. The status of each integration was reclassified into a 1-5 scale by using such a matrix (Table 8).

Table 7 - Reclassification Matrix

\begin{tabular}{|c|c|c|c|c|c|c|c|c|c|c|c|c|}
\hline \multirow{2}{*}{$\begin{array}{l}\text { Article } \\
\text { weight }\end{array}$} & \multicolumn{12}{|c|}{$\begin{array}{c}\text { Reclassification Value for } \\
\text { (Conclusiveness } \mathbf{x} \text { Influence) } \div 5\end{array}$} \\
\hline & ָั & ப̆ & : & $\stackrel{\infty}{0}$ & بـ & $\stackrel{\text { بִ }}{\text { - }}$ & $\stackrel{\infty}{\stackrel{\infty}{\sim}}$ & $\stackrel{\circ}{\text { i }}$ & $\stackrel{\text { ה }}{\text { ì }}$ & $\infty$ & H & in \\
\hline 1.65 & 1 & 1 & 1 & 1 & 1 & 2 & 2 & 2 & 2 & 2 & 4 & 4 \\
\hline 3.13 & 2 & 2 & 2 & 2 & 2 & 3 & 3 & 3 & 4 & 4 & 4 & 5 \\
\hline 4.56 & 3 & 3 & 3 & 3 & 3 & 4 & 4 & 4 & 4 & 4 & 5 & 5 \\
\hline 4.68 & 3 & 3 & 3 & 3 & 3 & 4 & 4 & 4 & 4 & 4 & 5 & 5 \\
\hline
\end{tabular}

Those reclassification values were multiplied to compute the overall levels corresponding to the investigation depth of each integration (Level of the Depth of Investigation); Table 9 shows the details.

\section{Results and Discussion}

Table 10 presents the Depths of Investigation of individual integrations. The same information is illustrated in Figure 1. Both show that the scientific communication between the hydro modeller and GIS modeller has been extensively studied.

The interaction between the management components and scientific components, denoted through the communication between HydroGIS modeller - decision-maker recipients, has an average depth of interest. Few researchers have conducted in-depth studies on internal integrations that appear in scientific modelling (between hydro-GISHydroGIS models).

Table 10 - Depth of Investigation of Each Integration

\begin{tabular}{|l|c|c|c|c|c|}
\hline \multirow{2}{*}{$\begin{array}{l}\text { Integration of } \\
\text { Components }\end{array}$} & \multicolumn{5}{|c|}{$\begin{array}{c}\text { No of documents based } \\
\text { on Investigation depth } \\
\text { of scale (1-5) }\end{array}$} \\
\cline { 2 - 6 } & $\mathbf{1}$ & $\mathbf{2}$ & $\mathbf{3}$ & $\mathbf{4}$ & $\mathbf{5}$ \\
\hline $\begin{array}{l}\text { Hydro modeller and } \\
\text { GIS modeller }\end{array}$ & & & & 1 & 12 \\
\hline $\begin{array}{l}\text { Hydro modeller/GIS } \\
\text { modeller and HydroGIS } \\
\text { modellers }\end{array}$ & & & 4 & 2 & 2 \\
\hline $\begin{array}{l}\text { HydroGIS modeller and } \\
\text { Decision-makers }\end{array}$ & 1 & & 3 & 4 & 6 \\
\hline $\begin{array}{l}\text { HydroGIS modeller and } \\
\text { Recipients }\end{array}$ & & 1 & 3 & 5 & 3 \\
\hline $\begin{array}{l}\text { Decision-maker and } \\
\text { recipients }\end{array}$ & 1 & 3 & & 7 \\
\hline
\end{tabular}

Figure 2 presents the average depth of investigations and the number of integrations in each document. There is a moderate negative correlation (-0.51) between the count of integrations in the document over the depth of integrations' investigation. It further shows that only one (01) paper had discussed four (04) Integrations while five (05) documents had discussed three (03) Integrations in a single document. Both results denote the absence of research in all five integrations and less attention paid to the integration of multiple components.

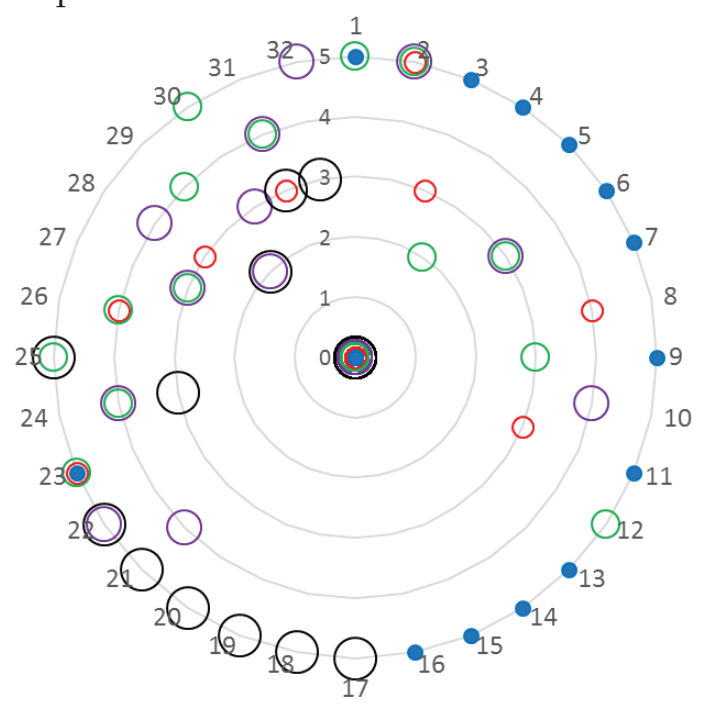

- Hydro Modeler and GIS modeler

O Hydro modeler/GIS modeler and HydroGIS modelers

O HydroGIS modeler and Decision makers

O HydroGIS modeler and Recipients

O Decision maker and recipients

*Depth of investigation is increased from centroid(0) to perimeter(5)

Figure 1 - Depth of Investigation in Documents Corresponding to each Integration

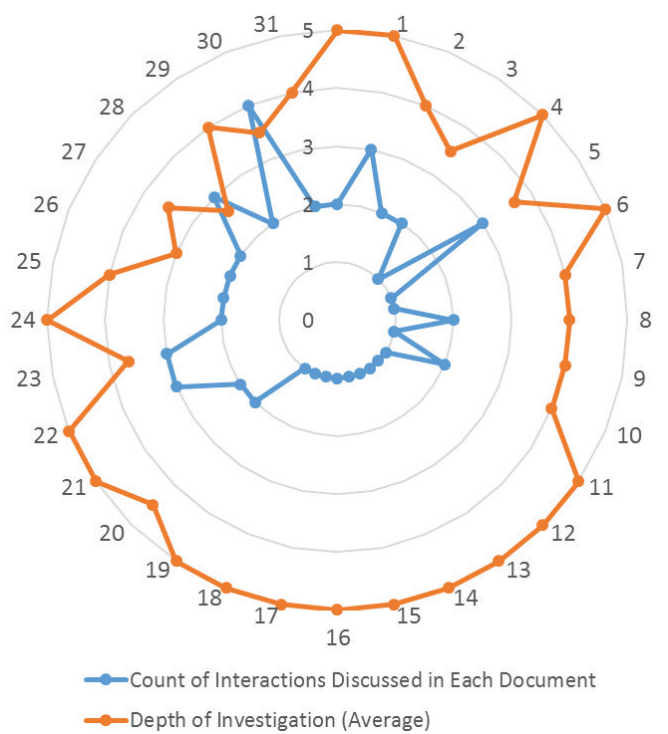

Figure 2 - Average Depth of Investigation and Number of Integrations in each Document 
Accordingly, recognition of the status of integrations in the HydroGIS tool development revealed very low coverage values that reflect the need for a significant effort for improved tool development (Figure 3).

The relative comparison implies that the transfer of HydroGIS requirements to the hydrologic and GIS model Integration is at a very low volume (0.94 out of 5), and the HydroGIS is lying in between management and scientific components. This indicates that the possibility of impractical flood management decision-making due to ineffective communication facilitates the systems to optimise scientific model requirements with stakeholder needs.

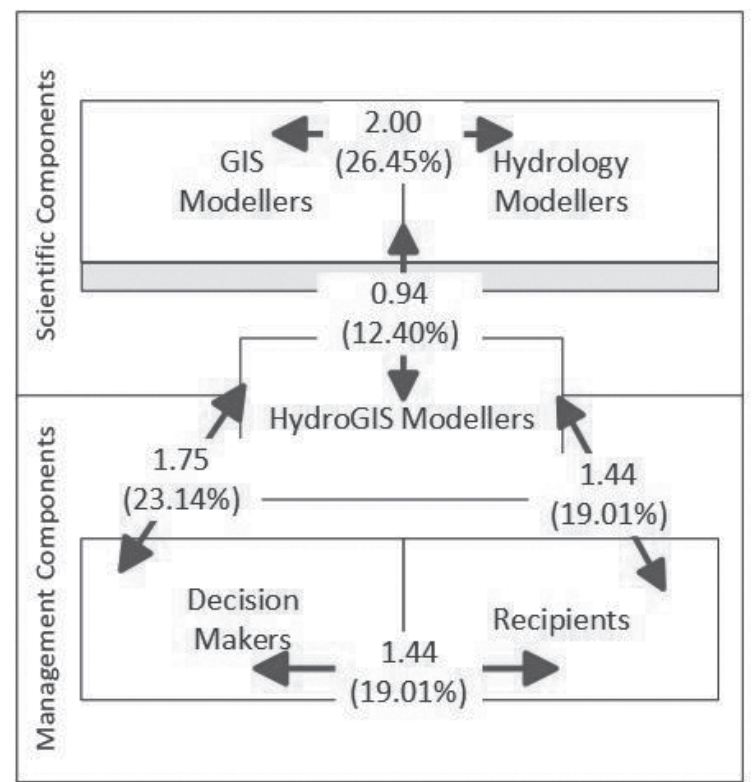

Figure 3 - The Average Depth of Investigation in Each Integration and its Comparison Level as a Percentage

\section{Conclusion}

Evaluation of the standard-setting in the HydroGIS model development for urban flood management enabled to identify the framework for stakeholder Integrations.

The rationalised qualitative assessment in the present work reveals that the current status of incorporating the stakeholder concerns is at a low level in all integrations.

The percentage values computed for the relative coverage signifies a gap in transferring of the decision-makers and recipients' concerns to hydro modellers and GIS modellers through HydroGIS modellers.

The HydroGIS modellers' concerns, which are optimising the scientific needs with management requirements, are vital as they are the focal facilitator of communication between scientific components and management components of the urban flood management system to develop sustainable decisions.

\section{References}

1. OSPHP, "Floods and Flash Floods," Floods and Flash Floods, http://www.houstontx.gov /health/OSPHP/Natural Disasters/ Floods.pdf, visited, 2014/9/2.

2. Sun, Z., Guo, H., Li, X., Huang, Q., \& Zhang, D., "Effect of Lulc Change on Surface Runoff in Urbanization Area," in Proceedings of the ASPRS Annual Conference, 2011, pp. 1-5.

3. Miller, J. D., Kim, H., Kjeldsen, T. R., Packman, J., Grebby, S., \& Dearden, R., "Assessing the Impact of Urbanization on Storm Runoff in a Peri-Urban Catchment Using Historical Change in Impervious Cover," J. Hydrol., Vol. 515, 2014, pp. 59-70.

4. WMO/GWP, “Urban Flood Management in a Changing Climate," 2012.

5. Chen, J., Hill, A. A., \& Urbano, L. D., “A GISBased Model for Urban Flood Inundation," J. Hydrol., Vol. 373, No. 1-2, 2009, pp. 184-192.

6. Clark, M. J., "Putting Water in Its Place: A Perspective on GIS in Hydrology and Water Management," Hydrol. Process., Vol. 12, November 1997, 1998, pp. 823-834.

7. Maidment, D. R., "GIS and Hydrologic Modeling - An Assessment of Progress," in Third International Conference on GIS and Environmental Modeling, 1996.

8. Chow, V. Te, Maidment, D. R., \& Mays, L. W., Applied Hydrology, Internatio. Singapore: McGraw-Hill, 1988.

9. Ogden, F. L., Garbrecht, J., Debarry, P. A., \& Johnson, L. E., "GIS and Distributed Watershed Models. II: Modules, Interfaces and Models," J. Hydrol. Eng., Vol. 6, No. 6, 2001, pp. 515-523.

10. Barik, R. K., Dubey, H., Samaddar, A. B., Gupta, R. D., \& Ray, P. K., "FogGIS: Fog Computing for Geospatial Big Data Analytics," in 2016 IEEE Uttar Pradesh Section International Conference on Electrical, Computer and Electronics Engineering (UPCON), 2016, pp. 613-618.

11. Paudel, M., "An Examination of Distributed Hydrologic Modeling Methods as Compared with Traditional Lumped Parameter Approaches," Brigham Young University, 2010.

12. Shamsi, U. M., "GIS and Water Resources Modeling :State-of-the-Art," J. Water Manag. Model., 1999.

13. Alcaraz, M., Vázquez-Suñé, E., Velasco, V., \& Criollo, R., "A Loosely Coupled GIS and Hydrogeological Modeling Framework," Environ. Earth Sci. Springer, Vol. 76, No. 382, 2017. 
14. Goodchild, M. F., "GIS in the Era of Big Data Les SIG à l'ère Des Big Data," Cybergeo Eur. J. Geogr., 2016.

15. Chappell, D., "GIS IN THE CLOUD," ESRI Exsample, http://www.esri.com/ library/ whitepapers/pdfs/gis-in-the-cloudchappell.pdf, Visited, 2017/7/5.

16. Bhor, H., "SOA for Web GIS Application in Cloud," Int. J. Res. Eng. Appl. Manag., Vol. 01, No. 04,2015 , pp. 1-4.

17. Kar, B., Sieber, R., Haklay, M., \& Ghose, R., "Public Participation GIS and Participatory GIS in the Era of GeoWeb," Cartogr. J., Vol. 53, No. 4, 2016, pp. 296-299.

18. Yang, C., Yu, M., Hu, F., Jiang, Y., \& Li, Y., "Computers, Environment and Urban Systems Utilizing Cloud Computing to Address Big Geospatial Data Challenges," Comput. Environ. Urban Syst., Vol. 61, 2017, pp. 120-128.

19. Devi, G. K., Ganasri, B. P., \& Dwarakish, G. S., "A Review on Hydrological Models," Aquat. Procedia, Elsevier, Vol. 4, 2015, pp. 1001-1007.

20. Coskun, H. G., Alganci, U., Eris, E., Agiralioglu, N., Cigizoglu, H. K., Yilmaz, L., \& Toprak, Z. F., "Remote Sensing and GIS Innovation with Hydrologic Modelling for Hydroelectric Power Plant (HPP) in Poorly Gauged Basins," Water Resour. Manag. Springer, Vol. 24, No. 14, 2010, pp. 3757-3772.

21. Pullar, D. \& Springer, D., “Towards Integrating GIS and Catchment Models," Environ. Model. Software, Elsevier, Vol. 15, 2000, pp. 451-459.

22. Loos, J. R. \& Rogers, S. H., “Understanding Stakeholder Preferences for Flood Adaptation Alternatives with Natural Capital Implications," Ecol. Soc., Vol. 21, No. 3, 2016.

23. Arnstein, S. R., "A Ladder of Citizen Participation," J. Am. Inst. Planners, Vol. 35, No. 4, 1969, pp. 216-224.

24. ACC/ISGWR, "International Conference on Water and the Environment: Development Issues for the 21st Century," Dublin Statement Rep. Conf., 1992, pp. I-VII, 1-55.

25. EU, Directive 2000/60/EC of the European Parliament and of the Council. 2000, pp. L327/1-L 327/72.

26. The Hague Ministerial Declaration, "Ministerial Declaration of the Hague on Water Security in the 21st Century," World Water, 2000, pp. 1-3.
27. Singh, V. P. \& Fiorentino, M., "Hydrologic Modeling with GIS," in Geographical Information Systems in Hydrology, V. P. Singh and M. Fiorentino, Eds. Boston: Kluwer Academic Publishers, 1996, pp. 10-11.

28. Assaf, H., Beek, E. van, Gijsbers, P., Jolma, A., Kaden, S., Kaltofen, M., Labadie, J. W., Loucks, D. P., Quinn, N. W. T., Sieber, J., Sulis, A., Werick, W. J., Wood, D. M., \& Borden, C., "Generic Simulation Models for Facilitating Stakeholder Involvement in Water Resources Planning and Management: A Comparison, Evaluation, and Identification of Future Needs.," in Developments in Integrated Environmental Assessment, Elsevier, Vol. 3, A. J. Jakeman, A. A. Voinov, A. E. Rizzoli, and S. H. Chen, Eds. Elsevier B.V., 2008, pp. 229-246.

29. Bhatt, G., Kumar, M., \& Duffy, C. J., “A Tightly Coupled GIS and Distributed Hydrologic Modeling Framework Environmental Modelling E Software," Vol. 62:70-84, 2014.

30. Comair, G. F., McKinney, D. C., Maidment, D. R., Espinoza, G., Sangiredy, H., Fayad, A., \& Salas, F. R., "Hydrology of the Jordan River Basin: A GIS-Based System to Better Guide Water Resources Management and Decision Making," Water Resour. Manag., Vol. 28, No. 4, 2014, pp. 933-946.

31. Huang, B. \& Jiang, B., "AVTOP: A Full Integration of TOPMODEL into GIS," Environ. Model. Softw., Vol. 17, No. 3, 2002, pp. 261-268.

32. Fotheringham, S. \& Rogerson, P., Editors, GIS and spatial analysis. London: Taylor \& Francis Ltd, 1994.

33. Voinov, A., Kolagani, N., McCall, M. K., Glynn, P. D., Kragt, M. E., Ostermann, F. O., Pierce, S. A., \& Ramu, P., "Modelling with Stakeholders Next Generation," Environ. Model. Softw., Vol. 77, January, 2016, pp. 196-220.

34. Cumiskey, L., Priest, S. J., Klijn, F., \& Juntti, M., "A Framework to Assess Integration in Flood Risk Management: Implications for Governance, Policy, and Practice," Ecol. Soc., Vol. 24(4), No. 17, 2019.

35. Sui, D. Z. \& Maggio, R. C., “Integrating GIS with Hydrological Modeling: Practices, Problems, and Prospects," Comput. Environ. Urban Syst., Vol. 23, No. 1, 1999, pp. 33-51.

36. Stuart, N. \& Stocks, C., "Hydrological Modelling within GIS; an Integrated Approach," Appl. Geogr. Inf. Syst. Hydrol. water Resour. Manag. Proc. Int. Conf. Vienna, 1993, No. 211, 1993, pp. 319-329. 
37. Henriksen, H. J., Refsgaard, J. C., Hojberg, A. L., Ferrand, N., Gijsbers, P., \& Scholten, H., "Harmonised Principles for Public Participation in Quality Assurance of Integrated Water Resources Modelling," Water Resour. Manag., Vol. 23, No. 12, 2009, pp. 2539-2554.

38. World Bank, "Municipal ICT Capacity and Its Impact on the Climate-Change Affected Urban Poor - The Case of Mozambique: A Poverty \& Social Impact Analysis Study," Washington, D.C, 2012.

39. Criollo, R., Velasco, V., Nardi, A., Manuel de Vries, L., Riera, C., Scheiber, L., Jurado, A., Brouyère, S., Pujades, E., Rossetto, R., \& Vázquez-Suñé, E., "AkvaGIS: An Open Source Tool for Water Quantity and Quality Management," Comput. Geosci., Vol. 127, November 2018, 2019, pp. $123-$ 132.

40. Hellmers, S., Manojlovic, N., Palmaricciotti, G., \& Fröhle, P., "Modelling Decentralised Systems for Urban Drainage and Flood Mitigation," J. Appl. Water Eng. Res., Vol. 5, No. 1, 2017, pp. 61-69.

41. Xu, Z. X., K, I., Schultz, G. A., \& Li, J. Y., "Integrated Hydrologic Modeling And Gis In Water Resources Management," J. Comput. Civ. Eng., Vol. 15, No. 3, 2001, pp. 217-223.

42. Kherde, R. V. \& Sawant, P. H., "Integrating Geographical Information Systems (GIS) with Hydrological Modelling - Applicability and Limitations," Int. J. Eng. Technol., Vol. 5, No. 4, 2013, pp. 3374-3381.

43. Pingale, S., Jat, M. K., \& Khare, D., "Integration of GIS in Environmental Modelling and Hydrological Analysis: A Review of Integration Technologies," in National Conference on Infrastructure Development in Civil Engineering in Civil Engineering, 2012.

44. Jessel, B. \& Jacobs, J., "Land Use Scenario Development and Stakeholder Involvement as Tools for Watershed Management within the Havel River Basin," Limnol. Elsevier, Vol. 35, No. 3, 2005, pp. 220-233.

45. Pradeep, R. M. M., "Who Are the Stakeholders in Flood Management Tools? : The Major Components Should Be Considered When Hydro-GIS-Stakeholder Flood Management Tool?," https://www.researchgate.net /post/Who_are_the_stakeholders_in_Floo d_Management_tools, Visited, 2020/12/1.
46. Saaty, T. L. \& Özdemir, M. S., "How Many Judges Should There Be in a Group?," Ann. Data Sci., Vol. 1, No. 3-4, 2014, pp. 359-368.

47. Rowe, G. \& Wright, G., "Expert Opinions in Forecasting: The Role of the Delphi Technique," 2001, Principles of Forecasting. Ed. J Armstrong pp. 125-144.

48. Pradeep, R. M. M. \& Wijesekera, N. T. S., "Selecting a Usability Evaluation User Group A Case Study the Development of a Hydro-GIS Tool Aiming Urban Flood Mitigation," in Civil Engineering Research for Industry Symposium (CERIS) - 2012, 2012.

49. Jern, M., "Web-Based 3D Visual User Interface to a Flood Forecasting System," in Geoinformation for Disaster Management, P. van Oosterom, S. Zlatanova, and E. M. Fendel, Eds. Berlin, Heidelberg: Springer, 2005, pp. 10211039.

50. Parker, P., Letcher, R., Jakeman, A., Beck, M., Harris, G., Argent, R., Hare, M., Pahl-Wostl, C., Voinov, A., Janssen, M., Sullivan, P., Scoccimarro, M., Friend, A., Sonnenshein, M., Barker, D., Matejicek, L., Odulaja, D., Deadman, P., Lim, K., Larocque, G., Tarikhi, P., Fletcher, C., Put, A., Maxwell, T., Charles, A., Breeze, H., Nakatani, N., Mudgal, S., Naito, W., Osidele, O., Eriksson, I., Kautsky, U., Kautsky aa, E., Naeslund ab, B., Kumblad ab, L., Park ac, R., Maltagliati ad, S., Girardin ae, P., Rizzoli af, A., Mauriello ag, D., Hoch ah, R., Pelletier ai, D., Reilly aj, J., Olafsdottir ak, R., \& Bin al, S., "Progress in Integrated Assessment and Modelling," Environ. Model. Softw., Vol. 17, May 2001, 2002, pp. 209-217.

51. Al-Sabhan, W., "Real-Time Mobile GIS Prototype: Design, Architecture, and Usability Study," IJCSNS Int. J. Comput. Sci. Netw. Secur., Vol. 10, No. 2, 2010, pp. 260-266.

52. Waleed, A. \& Steve, L., "Platforms and Viability of Mobile GIS in Real-Time Hydrological Models: A Review and Proposed Model," J. Syst. Inf. Technol., Vol. 13, No. 4, 2011, pp. 425444 .

53. Al-Sabhan, W., Mulligan, M., \& Blackburn, G. A., "A Real - Time Hydrological Model for Flood Prediction Using GIS and the WWW," Comput. Environ. Urban Syst., Vol. 27, 2003, pp. 9-32.

54. David, O., Ascough, J. C., Lloyd, W., Green, T. R., Rojas, K. W., Leavesley, G. H., \& Ahuja, L. R., "A Software Engineering Perspective on Environmental Modeling Framework Design: The Object Modeling System," Environ. Model. Softw., Vol. 39, 2013, pp. 201-213.

55. Andreadis, K. M., Das, N., Stampoulis, D., Ines, A., Fisher, J. B., Granger, S., Kawata, J., Han, E., \& Behrangi, A., "The Regional Hydrologic 
Extremes Assessment System: A Software Framework for Hydrologic Modeling and Data Assimilation," PLoS One, Vol. 12, No. 5, 2017, pp. 1-22.

56. Cázares-rodríguez, J. E., Vivoni, E. R., \& Mascaro, G., "Comparison of Two Watershed Models for Addressing Stakeholder Flood Mitigation Strategies: Case Study of Hurricane Alex in Monterrey, México," J. Hydrol. Eng., Vol. 22, No. 9, 2017, pp. 1-16.

57. Sanzana, P., Gironás, J., Braud, I., Branger, F., Rodriguez, F., Vargas, X., Hitschfeld, N., Muñoz, J. F., Vicuña, S., Mejía, A., \& Jankowfsky, S., “A GIS-Based Urban and Peri-Urban Landscape Representation Toolbox for Hydrological Distributed Modeling," Environ. Model. Softw., Vol. 91, May, 2017, pp. 168-185.

58. Leskens, J. G., Brugnach, M., Hoekstra, A. Y., \& Schuurmans, W., "Why Are Decisions in Flood Disaster Management so Poorly Supported by Information from Flood Models?," Environ. Model. Softw., Vol. 53, Mar. 2014, pp. 53-61.

59. Goodchild, M., Haining, R., Wise, S., \& Others, 12, "Integrating GIS and Spatial Data Analysis: Problem and Possibilities," Int. J. Geogr. Inf. Sci., Vol. 6, No. 5, 1992, pp. 407-423.

60. Stuart, N. \& Stocks, C., "Hydrological Modelling within GIS: An Integrated Appraoch," in Application of GIS in Hydrology and Water Resources: HydroGIS 93, 1993, pp. 319-329.

61. Mostert, E., "The Challenge of Public Participation," Water Policy, Vol. 5, 2003, pp. 179197.

62. Zhang, Y., Sugumaran, R., Mcbroom, M., Degroote, J., Kauten, R. L., \& Barten, P. K., “WebBased Spatial Decision Support System and Watershed Management with a Case Study," Int. J. Geosci., Vol. 2011, August, 2011, pp. 195-203.
63. Welsh, W. D., Vaze, J., Dutta, D., Rassam, D., Rahman, J. M., Jolly, I. D., Wallbrink, P., Podger, G. M., Bethune, M., Hardy, M. J., Teng, J., \& Lerat, J., "Environmental Modelling \& Software An Integrated Modelling Framework for Regulated River Systems," Environ. Model. Softw., Elsevier, Vol. 39, 2013, pp. 81-102.

64. Fatichi, S., Vivoni, E. R., Ogden, F. L., Ivanov, V. Y., Mirus, B., Gochis, D., Downer, C. W., Camporese, M., Davison, J. H., Ebel, B., Jones, N., Kim, J., Mascaro, G., Niswonger, R., Restrepo, P., Rigon, R., Shen, C., Sulis, M., \& Tarboton, D., “An Overview of Current Applications, Challenges, and Future Trends in Distributed Process-Based Models in Hydrology," J. Hydrol., Vol. 537, 2016, pp. 45-60.

65. Jha, A. K., Bloch, R., \& Lamond, J., Cities and Flooding: A Guide to Integrated Urban Flood Risk Management for the 21st Century. Washington DC: World Bank, 2012.

66. Maskrey, S. A., Mount, N. J., Thorne, C. R., \& Dryden, I., "Participatory Modelling for Stakeholder Involvement in the Development of Flood Risk Management Intervention Options," Environ. Model. Softw., Vol. 82, 2016, pp. 275-294.

67. Evers, M., Jonoski, A., Maksimovič, Č., Lange, L., Ochoa Rodriguez, S., Teklesadik, A., Cortes Arevalo, J., Almoradie, A., Eduardo Simões, N., Wang, L., \& Makropoulos, C., "Collaborative Modelling for Active Involvement of Stakeholders in Urban Flood Risk Management," Nat. Hazards Earth Syst. Sci., Vol. 12, No. 9, Sep. 2012, pp. 2821-2842. 


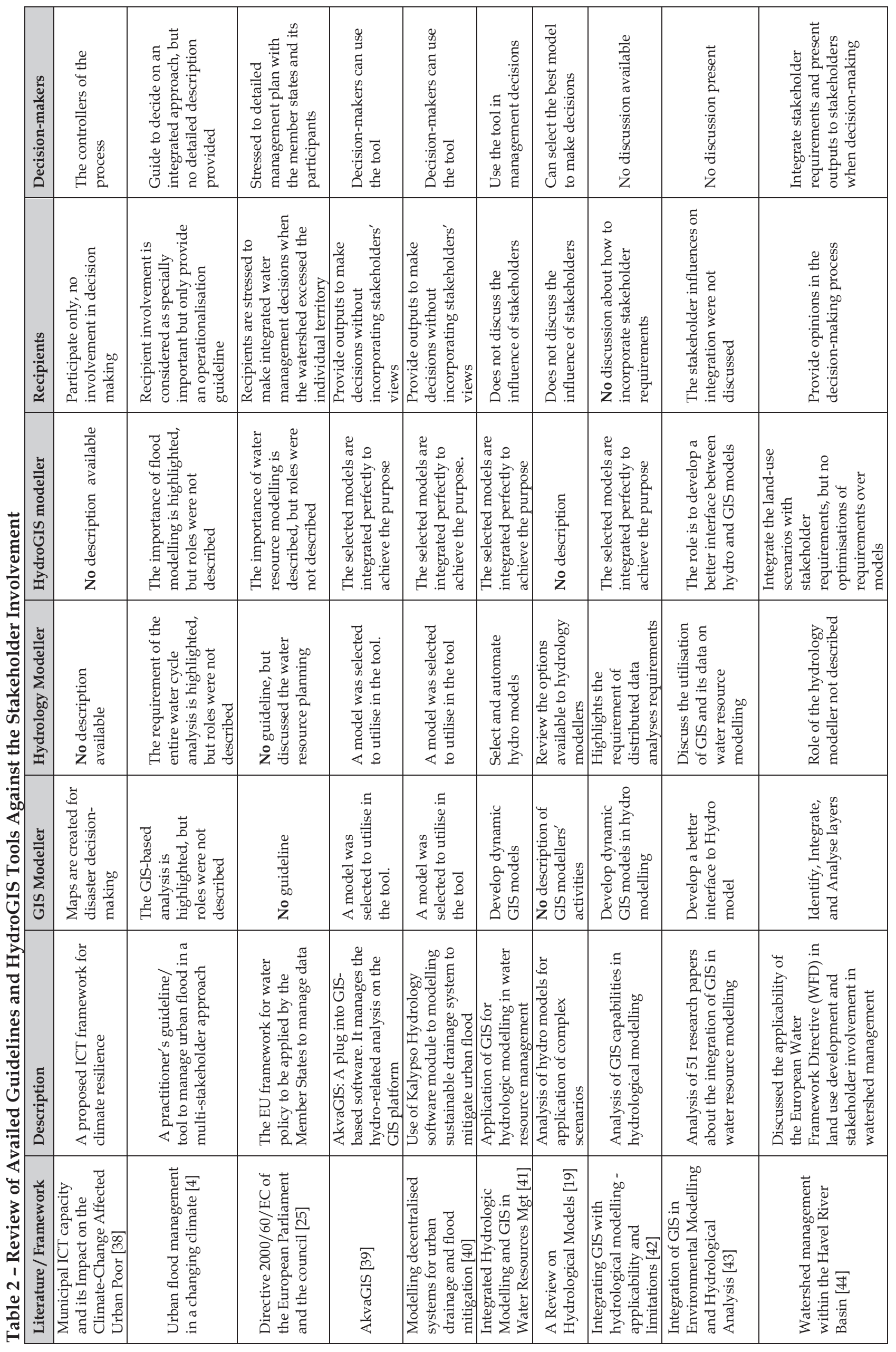




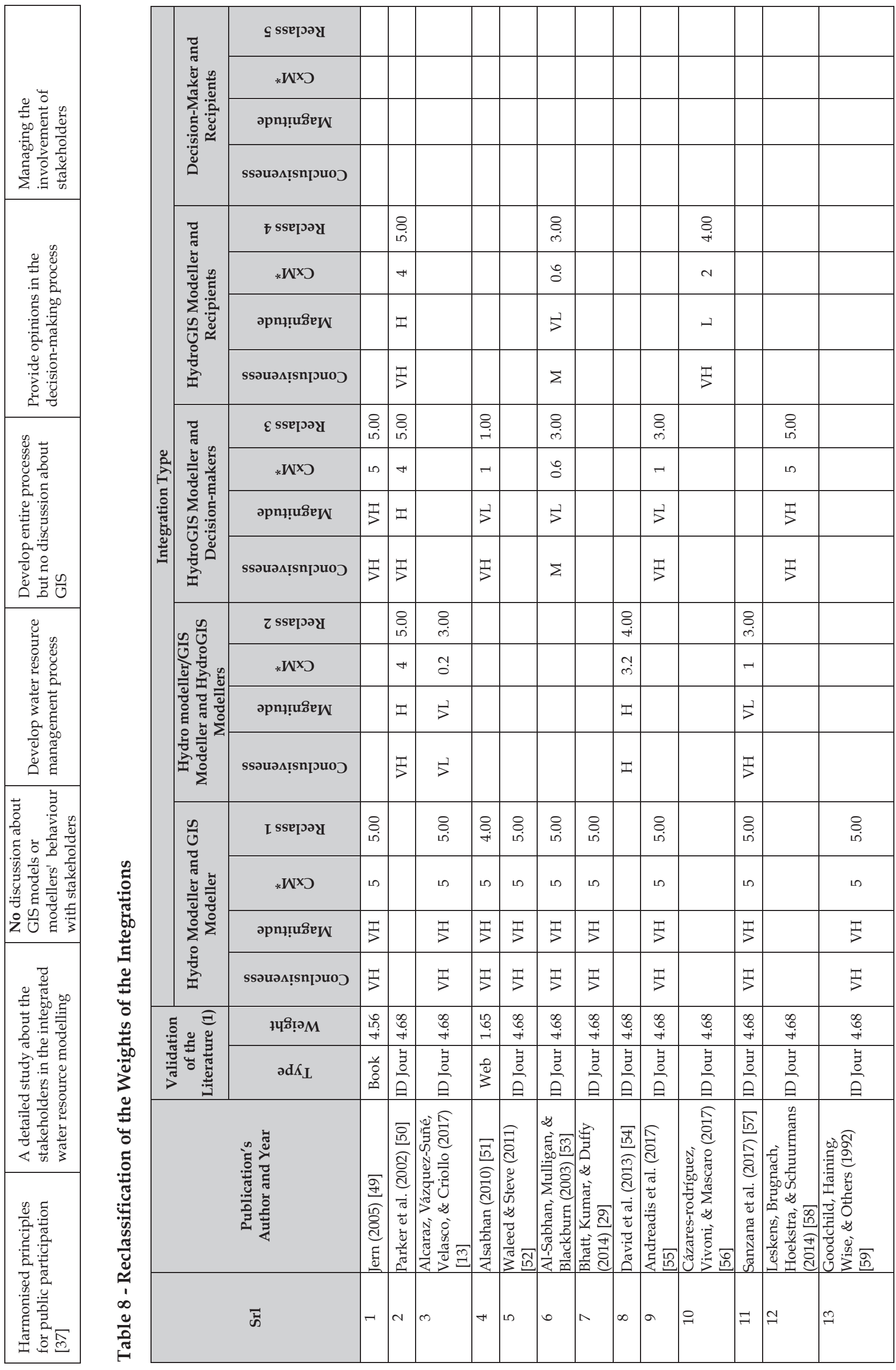




\begin{tabular}{|c|c|c|c|c|c|c|c|c|c|c|c|c|c|c|c|c|c|c|c|c|}
\hline \multirow{4}{*}{ 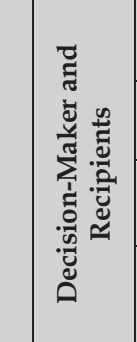 } & g ssepəəy & & & & $\begin{array}{l}8 \\
i \\
15\end{array}$ & $\begin{array}{l}8 \\
\text { in }\end{array}$ & $\begin{array}{l}8 \\
i n \\
\end{array}$ & $\stackrel{8}{\circ}$ & $\stackrel{8}{\circ}$ & $\underset{\text { in }}{\stackrel{8}{ }}$ & & $\begin{array}{l}8 \\
\dot{\infty} \\
\end{array}$ & $\begin{array}{c}8 \\
\text { in } \\
\end{array}$ & & & & 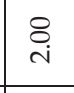 & & $\begin{array}{l}8 \\
\dot{\infty}\end{array}$ & $\begin{array}{l}8 \\
\infty \\
c\end{array}$ \\
\hline & $* \mathrm{~N}^{\mathrm{x} J}$ & & & & in & เ & in & เ & เ & in & & $\ddot{0}$ & in & & & & $\stackrel{\infty}{\infty}$ & & $\stackrel{\infty}{\circ}$ & $\infty$ \\
\hline & 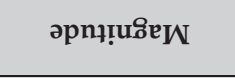 & & & & F & $\stackrel{I}{5}$ & $\stackrel{\Psi}{5}$ & $\stackrel{I}{5}$ & F & $\stackrel{F}{5}$ & & 5 & $\stackrel{F}{F}$ & & & & 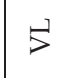 & & 5 & 5 \\
\hline & ssəuəی!̣sn[गuoว & & & & $\stackrel{F}{5}$ & F & $\stackrel{乛}{>}$ & $\stackrel{F}{s}$ & $\stackrel{F}{5}$ & $\stackrel{\Psi}{>}$ & & - & $\stackrel{P}{5}$ & & & & $\Psi$ & & I & I \\
\hline \multirow{4}{*}{ 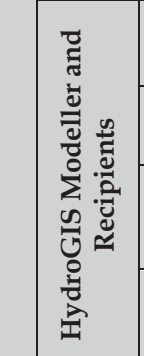 } & † ssepay & & & & & & & & $\underset{+}{8}$ & $\underset{i n}{8}$ & & \begin{tabular}{|l|} 
\\
\\
\end{tabular} & & & $\begin{array}{l} \\
\dot{\infty} \\
\end{array}$ & $\underset{+}{8}$ & $\underset{\text { i }}{\stackrel{\text { i }}{ }}$ & $\begin{array}{l}8 \\
\dot{\infty}\end{array}$ & $\underset{+}{\stackrel{8}{+}}$ & $\begin{array}{l}8 \\
\text { in } \\
\end{array}$ \\
\hline & ${ }_{*} \mathrm{WN}^{\mathrm{x}} \mathrm{J}$ & & & & & & & & $\stackrel{\circ}{-}$ & in & & $\stackrel{\infty}{+}$ & & & $\stackrel{0}{0}$ & ले & $\stackrel{\infty}{\circ}$ & $\stackrel{0}{\circ}$ & ì & in \\
\hline & әрпч!นове & & & & & & & & ــ & $\stackrel{F}{>}$ & & $\Sigma$ & & & 5 & I & 5 & 5 & $\Sigma$ & I \\
\hline & 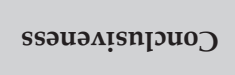 & & & & & & & & 㝳 & F & & $\Sigma$ & & & $\Sigma$ & I & $\Psi$ & $\Sigma$ & $\Psi$ & I \\
\hline \multirow{4}{*}{ 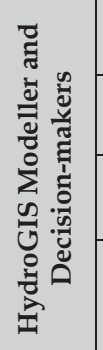 } & $\varepsilon$ ssepəəy & & & & & & & & & & $\begin{array}{c}8 \\
10 \\
10\end{array}$ & $\begin{array}{l}8 \\
+ \\
+\end{array}$ & \begin{tabular}{|c|}
8 \\
10 \\
\end{tabular} & $\begin{array}{l}\mathscr{P} \\
+ \\
+\end{array}$ & $\begin{array}{l}8 \\
\dot{\infty} \\
\end{array}$ & & $\underset{+}{\stackrel{8}{+}}$ & $\begin{array}{l}8 \\
10 \\
\end{array}$ & $\underset{+}{8}$ & \\
\hline & $* \mathrm{~W}^{\mathrm{x}} \mathrm{J}$ & & & & & & & & & & ம & \begin{tabular}{|l|}
$\infty$ \\
$\sim$ \\
\end{tabular} & เ & \begin{tabular}{|l|} 
\\
- \\
\end{tabular} & $\begin{array}{ll}\infty \\
0 \\
0\end{array}$ & & $\ddot{\infty}$ & n & $\stackrel{\vec{i}}{\mathrm{i}}$ & \\
\hline & 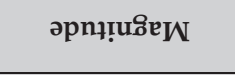 & & & & & & & & & & $\stackrel{P}{5}$ & $\Sigma$ & $\stackrel{m}{5}$ & 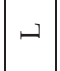 & $\$$ & & I & $\stackrel{P}{>}$ & $\Sigma$ & \\
\hline & ssәuәа!̣sn[рuоo & & & & & & & & & & $\stackrel{I}{5}$ & $\Sigma$ & $\stackrel{m}{5}$ & $I$ & $I$ & & $\Psi$ & F & $\Psi$ & \\
\hline \multirow{4}{*}{ 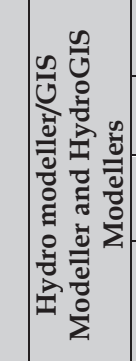 } & $z$ ssepory & & & & & & & & & & \begin{tabular}{|l|}
8 \\
10 \\
\end{tabular} & & & $\begin{array}{l}8 \\
\\
+\end{array}$ & & $\begin{array}{l}8 \\
\text { ल }\end{array}$ & & & $\begin{array}{l}8 \\
\text { ल }\end{array}$ & \\
\hline & ${ }_{*} \mathrm{~N}^{\mathrm{x}} \mathrm{J}$ & & & & & & & & & & in & & & 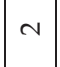 & & $\stackrel{\circ}{0}$ & & & $\stackrel{\infty}{0}$ & \\
\hline & 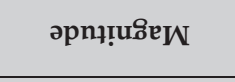 & & & & & & & & & & I & & & دـ & & 5 & & & $\risingdotseq$ & \\
\hline & 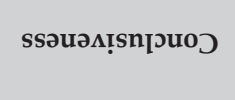 & & & & & & & & & & 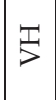 & & & $\stackrel{I}{5}$ & & $\Sigma$ & & & I & \\
\hline \multirow{4}{*}{ 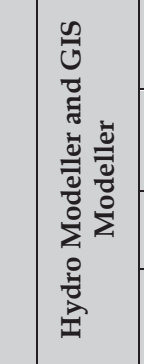 } & I ssepay & $\begin{array}{l}8 \\
i \\
\text { in }\end{array}$ & $\begin{array}{l}8 \\
\text { in }\end{array}$ & $\begin{array}{l}8 \\
\text { in } \\
\end{array}$ & & & & & & & $\begin{array}{c}8 \\
i n \\
10\end{array}$ & & & & & & & & & \\
\hline & ${ }_{*} \mathrm{~N}^{\mathrm{x}} \mathrm{J}$ & in & in & in & & & & & & & in & & & & & & & & & \\
\hline & әрпч!นове & $\stackrel{F}{5}$ & 5 & 5 & & & & & & & $\stackrel{I}{S}$ & & & & & & & & & \\
\hline & ssəuәм!̣sn[गuоว & $\$$ & F & F & & & & & & & $\stackrel{I}{s}$ & & & & & & & & & \\
\hline \multirow{2}{*}{ 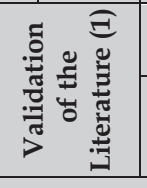 } & 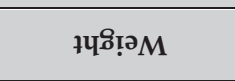 & 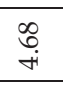 & $\begin{array}{l}\infty \\
+ \\
+\end{array}$ & $\begin{array}{l} \\
+ \\
+\end{array}$ & 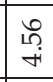 & $\stackrel{m}{m}$ & $\begin{array}{l}m \\
\vec{n}\end{array}$ & $\begin{array}{l}9 \\
\overrightarrow{5}\end{array}$ & $\begin{array}{l}\infty \\
\stackrel{\infty}{+} \\
+\end{array}$ & 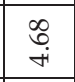 & $\begin{array}{l}\infty \\
\stackrel{\infty}{+} \\
+\end{array}$ & \begin{tabular}{|l|}
$\infty$ \\
$\stackrel{+}{+}$ \\
\end{tabular} & \begin{tabular}{l|}
$\infty$ \\
$\stackrel{+}{+}$ \\
\end{tabular} & \begin{tabular}{|l|}
$\infty$ \\
$\stackrel{+}{+}$ \\
\end{tabular} & \begin{tabular}{|l|}
$\infty$ \\
$\stackrel{+}{+}$ \\
+
\end{tabular} & $\begin{array}{l}\infty \\
+ \\
+\end{array}$ & $\stackrel{m}{\infty}$ & \begin{tabular}{|l|} 
\\
$\dot{+}$ \\
+
\end{tabular} & $\begin{array}{l}\infty \\
+\infty \\
+\end{array}$ & $\begin{array}{l}\infty \\
+ \\
\end{array}$ \\
\hline & $\operatorname{ad} \hat{K}_{\mathbf{L}}$ & $\frac{\bar{z}}{\sigma}$ & $\frac{\bar{z}}{0}$ & $\frac{\bar{z}}{\frac{3}{6}}$ & \begin{tabular}{|l|}
\multicolumn{2}{c}{} \\
\\
\end{tabular} & 忿星 & 召皇 & 忿 & $\frac{\dot{0}}{\mathrm{~g}}$ & $\frac{亏}{0}$ & \begin{tabular}{l}
\multirow{\Xi}{0}{} \\
\\
\end{tabular} & $\frac{\bar{\Xi}}{0}$ & \begin{tabular}{|l|}
\multirow{2}{0}{} \\
\multirow{2}{O}{} \\
\end{tabular} & 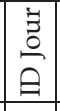 & \begin{tabular}{|l|}
$\stackrel{\Xi}{0}$ \\
\\
\end{tabular} & $\frac{\bar{z}}{0}$ & 忿星 & \begin{tabular}{|l|}
\multirow{2}{\circ}{} \\
\\
\end{tabular} & $\frac{亏}{0}$ & 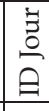 \\
\hline & 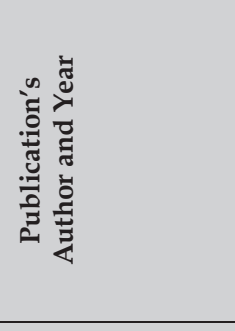 & 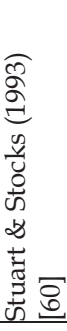 & $\begin{array}{l}7 \\
0 \\
0 \\
2 \\
2 \\
0 \\
0 \\
0 \\
6 \\
60 \\
0 \\
2 \\
2 \\
0 \\
3 \\
0 \\
0\end{array}$ & 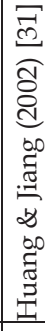 & 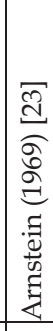 & 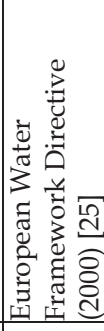 & 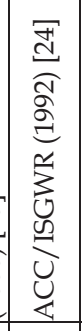 & 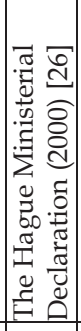 & 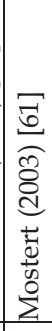 & 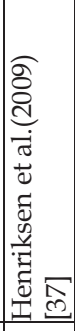 & 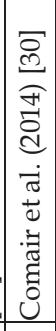 & 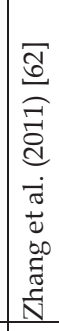 & 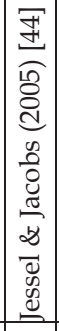 & 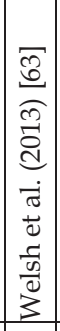 & 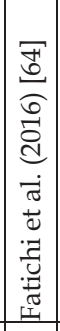 & 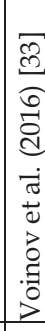 & 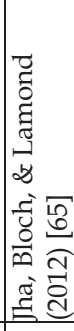 & 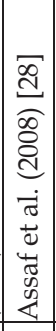 & 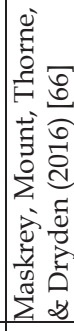 & 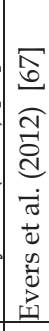 \\
\hline & के & $\ddot{r}$ & $\stackrel{10}{\longrightarrow}$ & $\because$ & 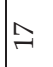 & $\stackrel{\infty}{\rightleftharpoons}$ & $\stackrel{2}{2}$ & ฉิ & $\vec{\lambda}$ & ส & $\ddot{2}$ & $\ddot{N}$ & $\stackrel{2}{2}$ & $\underset{N}{2}$ & $\hat{\lambda}$ & $\infty$ & ते & i & $\vec{m}$ & लै \\
\hline
\end{tabular}




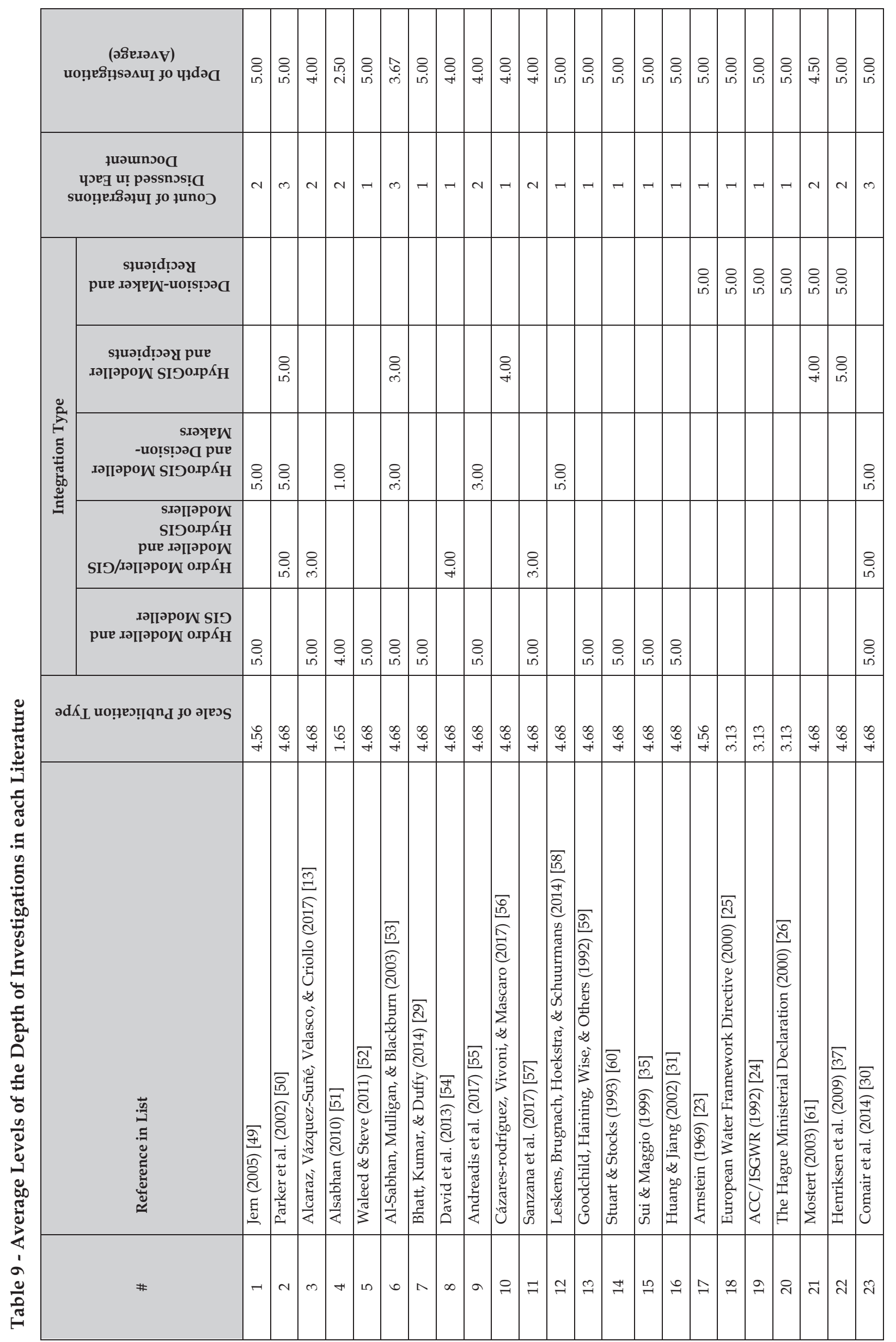




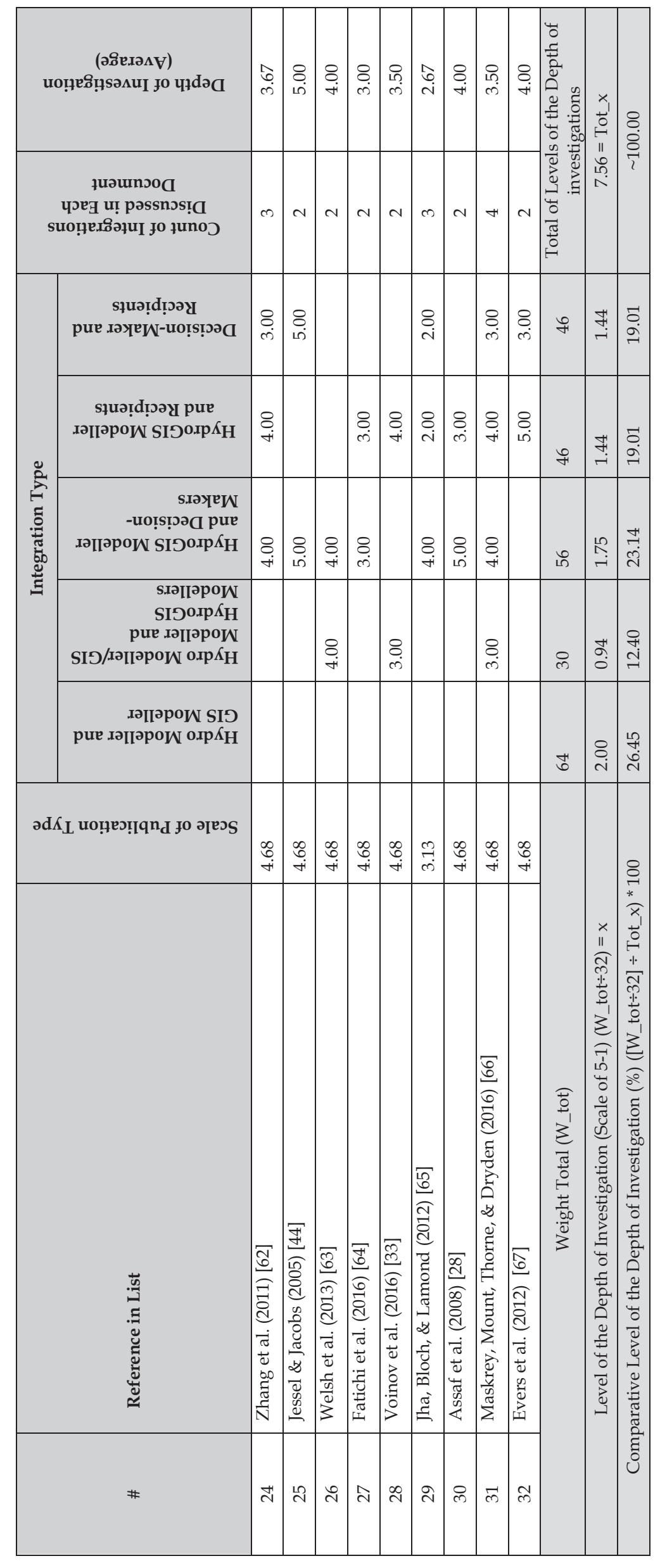

